\title{
Editorial
}

\section{Learning to lobby}

Interest Groups \& Advocacy (2015) 4, 1-6. doi:10.1057/iga.2014.22

We often hear - in scholarly work, in the mass media, and at practitioner conferences - of the 'lobbying profession,' but I argue (McGrath, 2005) that although lobbying is now a well-established occupation it still falls far short everywhere - of having attained professional status. Jordan's (1991) direct challenge could be asked with equal validity in any nation: 'Lobbying in Britain may be increasingly professional in that more and more decision making rests on complicated arguments about non-obvious impacts of policies on particular clienteles. But is it a profession?' (p. 41).

Among the key elements of any profession are: a set of common values; membership in strong representative organisations; adherence to professional norms; an intellectual tradition and body of knowledge; and technical skills acquired through professional training (Grunig and Hunt, 1984). Cutting across several of these factors is the question of how lobbyists are educated and trained, in terms not only of the specific policy and process knowledge they need but also of the way in which they are socialized into the industry's standards and expectations. In a classic text, Berry (1977, p. 92) noted that, 'No one has interviewed the people who actually hire staff lobbyists or lobbyist entrepreneurs to ask them about what qualities they look for. It is entirely possible that employers have no clear idea either of what qualifies a person to be a lobbyist.' We have some anecdotal insight into a number of the personal qualities and characteristics which an effective lobbyist appears to need (McGrath, 2006), but there is still very little systematic empirical evidence which might answer the question posed by Berry. Nor can we say with any certainty how best lobbyists or aspiring lobbyists can gain the skills, knowledge and qualities necessary for successful advocacy.

These are issues which the older and more traditional professions have already wrestled with and essentially resolved. Other industries have also been taking steps in the direction of professionalisation for some time. One closely related field, that of public relations, has been much more proactive in this area than has lobbying. The Public Relations Division of the Association for Education in Journalism and Mass Communication, for instance, publishes an occasional monograph series on 'Teaching Public Relations' (www.aejmc.net/PR/teach.htm). The Global Alliance 
for Public Relations and Communication Management has been instrumental in the production of a number of reports on undergraduate and post-graduate curricula (Tench and Deflagbe, 2008; Toth and Aldoory, 2010; Commission on Public Relations Education, 2012), all of which build upon earlier studies (IPRA, 1982; Commission on Public Relations Education, 2006).

In addition, it is noticeable that other academic disciplines have engaged in much more vigorous debate than has the field of interest groups / lobbying over the content - and desirability - of a generally recognised core curriculum. Even if we look only at political science, we can find such discussions around EU studies (Rumford and Murray, 2003; Umbach and Scholl, 2003), public administration (Henry et al, 2009), international studies (Breuning and Quinn, 2011) and political economy (Stilwell, 2005), for example. Unfortunately, we see few signs to date of similar conversations taking place among scholars of interest groups and lobbying. Certainly, none have provided such a sustained contribution as has been made in the related field of public affairs by Fleisher (2001, 2003, 2007; Fleisher and Blair, 1999).

The contributions collected in this special issue reflect on the issues surrounding the education and training of lobbyists from a range of perspectives and experiences. The issue opens with a piece by Thomas Holyoke, Heath Brown and Timothy LaPira, who note that almost 90 per cent of registered lobbyists in Washington DC are over 35 years of age, and thus argue that specialist lobbying education is best suited to the (post)graduate level. Holyoke et al point to three broad areas which can be taught to aspiring lobbyists - knowledge (both of the political process and of policy domains), communication and messaging (such as how to most persuasively frame an argument), and relationship management (which for them includes the ethical standards lobbyists must follow). They conclude by outlining the topics which students might encounter in both a lobbying simulation and an overall Master's curriculum. The practical, real world, emphasis of their suggested programme is highlighted by the inclusion of a compulsory internship or practicum component.

Shifting from the United States to the Netherlands, Arco Timmermans' review of developments in public affairs there over the last 15 years connects university programmes with the process of professionalisation. One feature of this special issue is that it reflects our collective inability thus far to agree on terminology - so three of the articles contain 'lobbying' or 'lobbyist' in their title, while two refer instead to 'public affairs' and another deals with 'public policy advocacy'. This divide is mirrored geographically, with two of the three US-focused articles using 'lobbying', and two of the three EU-based articles preferring 'public affairs'. Here, Timmermans notes evidence that while 'lobbying' was increasingly used in the last century and became a more popular expression than 'public affairs' in the mid-1970s, that situation has more recently been in reverse with 'public affairs' gaining in usage. In the case of the Netherlands, the Dutch Association for Public Affairs (BVPA) which was loosely formed in 1999 and more formally established in 2002, has since grown to over 600 members. The goals of BVPA would be familiar to all similar 
national associations in the field - to encourage professionalisation, to promote the lobbying industry and enhance its reputation - but the group has also taken an innovative step in collaborating with an university to establish and fund a Chair in Public Affairs, which Arco Timmermans holds. From this unique vantage point, Timmermans concludes from surveys of Dutch practitioners that a more systematic approach is needed to develop the skills, knowledge and competences required by lobbyists. He argues that our body of knowledge should be focused on three principal elements: strategic intelligence on policy issues and venues; the impact of social and political capital on trust and reputation; and the internal organisational embedding of public affairs. Until these components are built into interdisciplinary Master's programmes, Timmermans suggests that it will be problematic to make substantial progress on the professionalisation of the industry (including potentially the accreditation and licensing of practitioners).

Echoing, in a US context, Timmermans' call for more expansive engagement between academics and professionals, Patrick Griffin and James Thurber draw on their experience of having run American University's Public Affairs and Advocacy Institute (PAAI) for almost a quarter of a century. Outlining their curriculum, Griffin and Thurber draw attention to how practicing lobbyists can be used as more than simply occasional guest speakers, by serving as mentors to groups of students as they develop practical assignments to formulate lobbying campaigns. Indeed, the whole PAAI curriculum is built around what Griffin and Thurber term 'The Campaign Mindset', in that each module focuses on a component of a comprehensive lobbying strategy, aiming to produce ultimately a multidimensional and dynamic advocacy effort capable of achieving policy change in the real world. Importantly, in addition to imparting knowledge about policymaking and technical skills for effective advocacy, Griffin and Thurber recognise that lobbying is an art, which apprentices can only fully understand through exposure to more experienced and seasoned craftsmen and women.

Returning to Europe, the next article in this special issue reveals how a successful public affairs programme in Austria has been developed. Julia Wippersberg, Nicole Wagner and Klaus Lojka offer an overview of their model of a part-time, two-year, Master's course. Although many such programmes around the world provide a blend of academic theory and professional expertise, the focus is often primarily on the practical; here, though, the course is explicitly designed with a very thorough theoretical foundation. So, the entire first year of the programme is dominated by topics such as communication theory, economics, sociology, psychology, history, politics and international relations, law and business, before moving on in the second year to the lobbying tactics and techniques which are more common to other programmes. The establishment of this course marks a significant point in the progress towards professionalisation in Austria, and interestingly (even, unusually) students must undertake an entrance exam (including writing a lobbying position paper) in order to be accepted onto the programme. 
We next return to a US perspective this time one offered by a practitioner. Howard Marlowe, a two-time former president of the American League of Lobbyists (now renamed the Association of Government Relations Professionals (AGRP)), regards a core body of knowledge as taught by reputable educational programmes as essential if lobbying is to advance to professional status. He describes the content and purpose of the ARGP's Lobbying Certificate Program that has run since 2006, and suggests a novel route by which this course - and others offered at university level - could potentially be recognised by Congress, with successful completion required of all those lobbyists who must register under current disclosure legislation. Marlowe notes that someone who works as a barber in Washington must attend a prescribed course, pass exams, and undertake continuing education throughout their career in order to be licensed to offer their services to the public. Not so for a Washington lobbyist.

The final article in this special issue (and the most empirical), by Marco Althaus, takes up the theme of what competences and knowledge lobbyists need to possess, in the German context. He begins by examining the various entry routes into the industry (including apprenticeship models and traineeships), and goes on to analyse the skills requested in job ads placed by lobbying employers (associations, companies and consultancies). Althaus sees lobbying as essentially boundary spanning, a blend of art and science, and finds little consensus across the industry on even the most basic terminology. His research provides some of the most concrete evidence we have to date on the human capital dimension of the lobbying industry, and could usefully be replicated in other nations.

The efforts of all the authors included here to produce their work to a relatively strict deadline are much appreciated, as indeed are those of the authors whose submitted articles could not be included. Thanks also to those who reviewed submissions for this special issue: Steve Billet, Justin Fisher, Phil Harris, Ron Hrebenar, Grant Jordan, Peter Koppl, Bird Loomis, David Lowery, Christine Mahoney, Kevin Moloney, Danny Moss, Gill Morris, Tony Nownes, Ian Somerville, Clive Thomas and Stuart Thomson.

This special issue can only accomplish so much in itself, but the editors and contributors offer it as a starting point for a more sustained conversation between academics and practitioners over the coming years. For myself, I regard the professionalisation of the lobbying industry as the single most fundamental question with which the industry has to engage. No fundamental element of the public policymaking process can expect to survive unscathed indefinitely if it is broadly regarded by the public as illegitimate. In its annual survey of perceptions about the honesty and ethics of various professions, Gallup (2008, 2013) generally finds lobbyists at the bottom of the list - in 2013, only 6 per cent rated lobbyists as 'high' or 'very high' for ethical standards compared with 82 per cent for nurses, and in 2008 lobbyists hit a record across all professions with 64 per cent saying that their integrity was 'low' or 'very low'. Similarly, a 2014 Vanity Fair poll saw lobbyists top the list (with 26 per cent) of the 'greediest' professions. 
The only way in which lobbying can achieve greater public legitimacy is for the industry to make progress towards greater professionalisation (McGrath, 2005). That encompasses a wide agenda - including more transparency and accountability, effective professional associations, a greater willingness by lobbyists to educate the public about the virtues of interest representation, the articulation of a common set of professional norms and values. One crucial element in the professional edifice is certainly the development of recognised higher education courses and qualifications. No consensus yet exists as to what a lobbying curriculum should contain, or how academic content and experiential learning can be balanced. We continue to debate whether lobbying skills even can be taught (Goldman, 2012) - although the authors included in this special issue all believe that they can. The path to professionalisation depends upon greater dialogue taking place between the academic and professional communities. One useful advance would be to establish an international association bringing together lobbyists' associations and academics who research and teach lobbying, but that first requires some entrepreneurs with seed funding to get such a group off the ground. Each of us, though, scholars and practitioners alike, can individually contribute by giving voice to our own thoughts and perspectives - in articles and conference papers, in departmental curriculum meetings and in professional groups. If this special issue can help stimulate increased discussion around the education and training of lobbyists, it will have played a useful role.

\section{References}

Berry, J.M. (1977) Lobbying for the People. Princeton, NJ: Princeton University Press.

Breuning, M. and Quinn, J.J. (2011) The international studies minor in practice: Program offferings and student choices. Journal of Political Science Education 7(2): 173-195.

Commission on Public Relations Educations (2006) The Professional Bond: Public Relations Education for the 21st Century. New York: Commission on Public Relations Education, http://www.commpred .org/_uploads/report2-full.pdf, accessed 7 January 2015.

Commission on Public Relations Education (2012) Standards for a Master's Degree in Public Relations: Educating for Complexity. Charlotte, NC: Commission on Public Relations Education, http://www .globalalliancepr.org/website/sites/default/files/nolie/Research/Educating\%20for\%20Complexity_ Oct2012\%20final.pdf, accessed 7 January 2015.

Fleisher, C.S. and Blair, N.M. (1999) Tracing the parallel evolution of public affairs and public relations: An examination of practice, scholarship and teaching. Journal of Communication Management 3(3): 276-292.

Fleisher, C.S. (2001) The state of North American higher education in corporate public affairs. Journal of Public Affairs 1(4): 436-440.

Fleisher, C.S. (2003) The development of competencies in international public affairs. Journal of Public Affairs 3(1): 76-82.

Fleisher, C.S. (2007) Developing the public affairs body of knowledge. Journal of Public Affairs 7(3): 281-290.

Gallup (2008) Nurses shine, bankers slump in ethics ratings, http://www.gallup.com/poll/112264/NursesShine-While-Bankers-Slump-Ethics-Ratings.aspx, accessed 7 January 2015. 
Gallup (2013) Honesty and ethics rating of clergy slides to new low, http://www.gallup.com/poll/166298/ honesty-ethics-rating-clergy-slides-new-low.aspx.

Goldman, T.R. (2012) Forget creativity: Can lobbying be taught? Washington Post 19 November, http://www.washingtonpost.com/lifestyle/style/forget-creativity-can-lobbying-be-taught/2012/11/18/ a5c29ae4-16eb-11e2-8792-cf5305eddf60_story.html, accessed 7 January 2015.

Grunig, J.E. and Hunt, T. (1984) Managing Public Relations. Fort Worth, TX: Harcourt Brace Jovanovich.

Henry, N., Goodsell, C.T., Lynn, L.E., Stivers, C. and Walmsley, G. (2009) Understanding excellence in public administration: The report of the task force on educating for excellence in the master of public administration degree of the American society for public administration. Journal of Public Affairs Education 15(2): 117-133.

IPRA (1982) A Model for Public Relations Education for Professional Practice. London: International Public Relations Association, http://www.ipra.org/pdf/1982-a_model_for_pr_education_for_professional_ practice.pdf, accessed 7 January 2015.

Jordan, G., ed. (1991) The professional persuaders. In: The Commercial Lobbyists. Aberdeen: Aberdeen University Press, pp. 13-46.

McGrath, C. (2005) Towards a lobbying profession: Developing the industry's reputation, education and representation. Journal of Public Affairs 5(2): 124-135.

McGrath, C. (2006) The ideal lobbyist: Personal characteristics of effective lobbyists. Journal of Communication Management 10(1): 67-79.

Rumford, C. and Murray, P. (2003) Do we need a core curriculum in European Union studies? European Political Science 2(4): 85-92.

Stilwell, F. (2005) Teaching political economy: Curriculum and pedagogy. Australasian Journal of Economics Education 2(1/2): 66-82.

Tench, R. and Deflagbe, D. (2008) Towards a Global Curriculum: A Summary of Literature Concerning Public Relations Education, Professionalism and Globalisation. Lugano: Global Alliance for Public Relations and Communication Management, http://www.globalalliancepr.org/website/sites/default/ files/fedeles/Global\%20Curriculum/Towards\%20a\%20Global\%20Curriculum\%20-\%20final\%20Feb1 .pdf, accessed 7 January 2015.

Toth, E. and Aldoory, L. (2010) A First Look: An In-Depth Analysis of Global Public Relations Education. Lugano: Global Alliance for Public Relations and Communication Management, http://www.global alliancepr.org/website/sites/default/files/fedeles/Global\%20Curriculum/GlobalresearchreportPDF.pdf, accessed 7 January 2015.

Umbach, G. and Scholl, B. (2003) Towards a core curriculum in EU studies. European Political Science 2(2): 71-80.

Vanity Fair (2013) Want, want, want. December, p. 66.

Conor McGrath Independent Scholar, Ireland. conor.p.mcgrath@gmail.com 